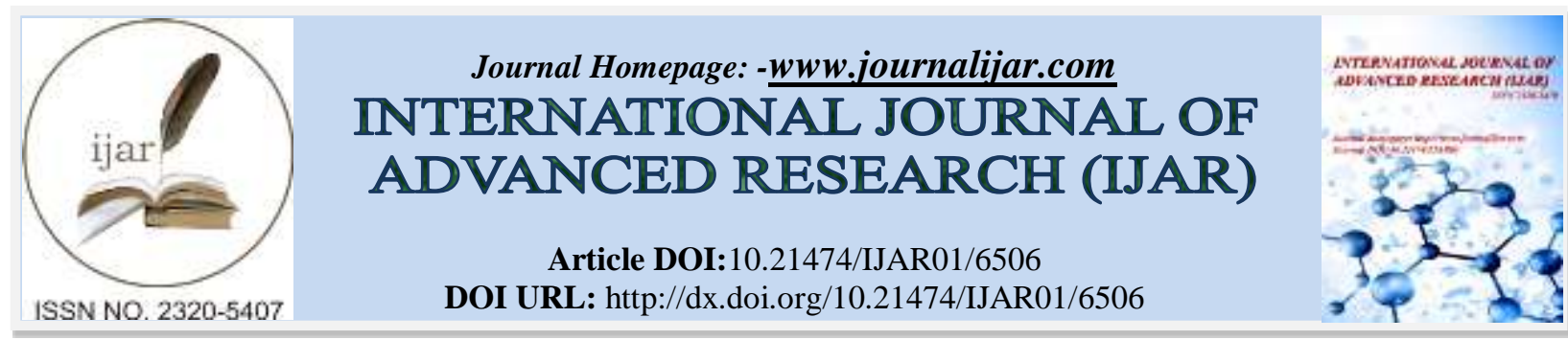

RESEARCH ARTICLE

\title{
STUDY OF THE PHYTOPLANKTON POPULATION IN THE MBOI KA'E STREAM, ENCARNACIÓN, PARAGUAY.
}

\author{
Albrecht $M^{1}$ and Rodríguez $E^{2}$. \\ 1. Doctorado en Gestión Ambiental. Escuela de Pos Grado Universidad Nacional de Itapúa. - Encarnación, \\ Paraguay. \\ 2. Universidad Nacional de Itapúa, Facultad de Ciencias y Tecnología- Encarnación, Paraguay.
}

\section{Manuscript Info}

\section{Manuscript History}

Received: 11 December 2017

Final Accepted: 13 January 2018

Published: February 2018

Keywords:-

Phytoplankton, seasons, class, watershed.

\begin{abstract}
The study was conducted during the four seasons of 2015 in the water basin of the Mboi Ka'e stream in the city of Encarnación. The objective of the research was to evaluate the phytoplankton population in the Mboi Ka'e watershed in the four seasons of the year. The samples were collected in six different points included within the study area, in each of the seasons of the year by means of the water filtration method through an aperture mesh network of $25 \mu \mathrm{m}$ were fixed with 5\% formaldehyde. The analyzes were carried out in the laboratory of the Faculty of Science and Technology of the State University of Itapúa with 10x, 40x, 100x optical microscope. For these, Sedwick-Rafter camera was used by random fields or bands. In the study, three classes of phytoplankton Cyanophyta, Chlorophyta and Bacillariophyta were identified. An analysis of variance (ANOVA) was performed for each class identified in the four seasons of the year. The ANOVA presented a significant difference for the Cyanophyta class in relation to the seasons, the Chlorophyta class showed no significant difference for the seasons as for the number of individuals (cells, colonies or filaments) while the Bacillariophyta class presented a difference not significant for the seasons of the year while the difference was highly significant for the number of cells. Results yielded that in the watershed of the Mboi Ka'e stream, the phytoplankton population is dominated by three main classes, Cyanophyta, Chlorophyta and Bacillariophyta.
\end{abstract}

Copy Right, IJAR, 2018,. All rights reserved.

\section{Introduction:-}

The district of Encarnación is characterized by having different water basins consisting of streams and rivers, the modifications of the ecosystems can be influenced by the physical-chemical and biological characteristics, thus registering alterations in the water quality of the basins.

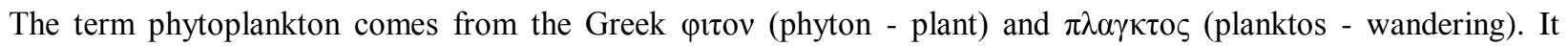
includes organisms that form microscopic photosynthetic communities that live suspended in the photic zone of the water column (Reynolds, 1984).

Corresponding Author:- Albrecht M.

Address: -Doctorado en Gestión Ambiental. Escuela de Pos Grado Universidad Nacional de Itapúa. - 
During the initial stage of the process of production of organic matter in water systems (oceans and rivers) phytoplankton is formed and occupies the base of the traditional trophic chain, it comprises the largest portion of primary producing organisms of the ocean and is the basic food for consumers (Platt et al., 1992). Phytoplankton plays a very important role as the basis of trophic networks and as indicators of water quality (Oliva-Oliva-Martínez et al., 2014).

Phytoplankton algae are important in the life of man. They have been proposed and used as food supplements, source of omega-type fatty acids, antioxidants, in addition to being proposed to help in the restoration of ecosystems, the reduction of greenhouse emissions and even as producers of biofuels (Oliva-Martínez et al. 2014).

The basin of the Paraná river presents within its population of dominant phytoplankton the Cryptophyceae and Bacillariophyceae, in the different regions of the reservoir. At the beginning of autumn and the end of spring, there was an increase in the density of Cyanobacteria in the seasons with the longest residence time of the water. The composition and density of the phytoplankton showed a marked spatial and temporal variation, mainly determined by the variations of the hydro-sedimentological regime of the Paraná River (Meichtry de Zaburlín et al., 2013).

Therefore, the study was proposed with the objective of evaluating the phytoplankton population in the Mboi Ka'e stream basin in the four seasons of the year.

\section{Materials and Methods:-}

The study was carried out in the sub reservoir of the Mboi Ka'e stream in the county of Encarnación- Itapúa Paraguay in 2015.

The climate of the place is sub-tropical with average temperatures of $21^{\circ} \mathrm{C}$ and an average precipitation of 1800 $\mathrm{mm} /$ year.

Samples of six points were collected as shown (figure 1) according to the methodology proposed by Thorton et al. (1990).

The phytoplankton sampling was performed by filtering 50 liters of water through an aperture mesh network of 25 $\mu \mathrm{m}$ were fixed with $5 \%$ formaldehyde. They were carried out in the four seasons of the year (spring, summer, autumn and winter). The results were expressed in number of individuals (cells, colonies or filaments) per milliliter per identified classes.

The quantitative analysis was carried out by means of a 10x, 40x, 100x optical microscope. Sedwick-Rafter chamber was used for random fields or bands. For the specific systematic determination of each group, different bibliographies were consulted (Huber-Testalozzi 1955, Bourelly, 1970, 1972, 1981, Prescott, 1982, Komarek \& Fott, 1983, Conforti \& Tell, 1986, Kramer \& Lange-Bertalot, 1986, 1991, Anagnostidis \& Komarek, 1989, Bicudo \& Menezes, 2006, Dos Santos, 2016).

The obtained data were subjected to analysis of variance, the means that presented significant difference were compared by the Duncan test $0.05 \%$. 


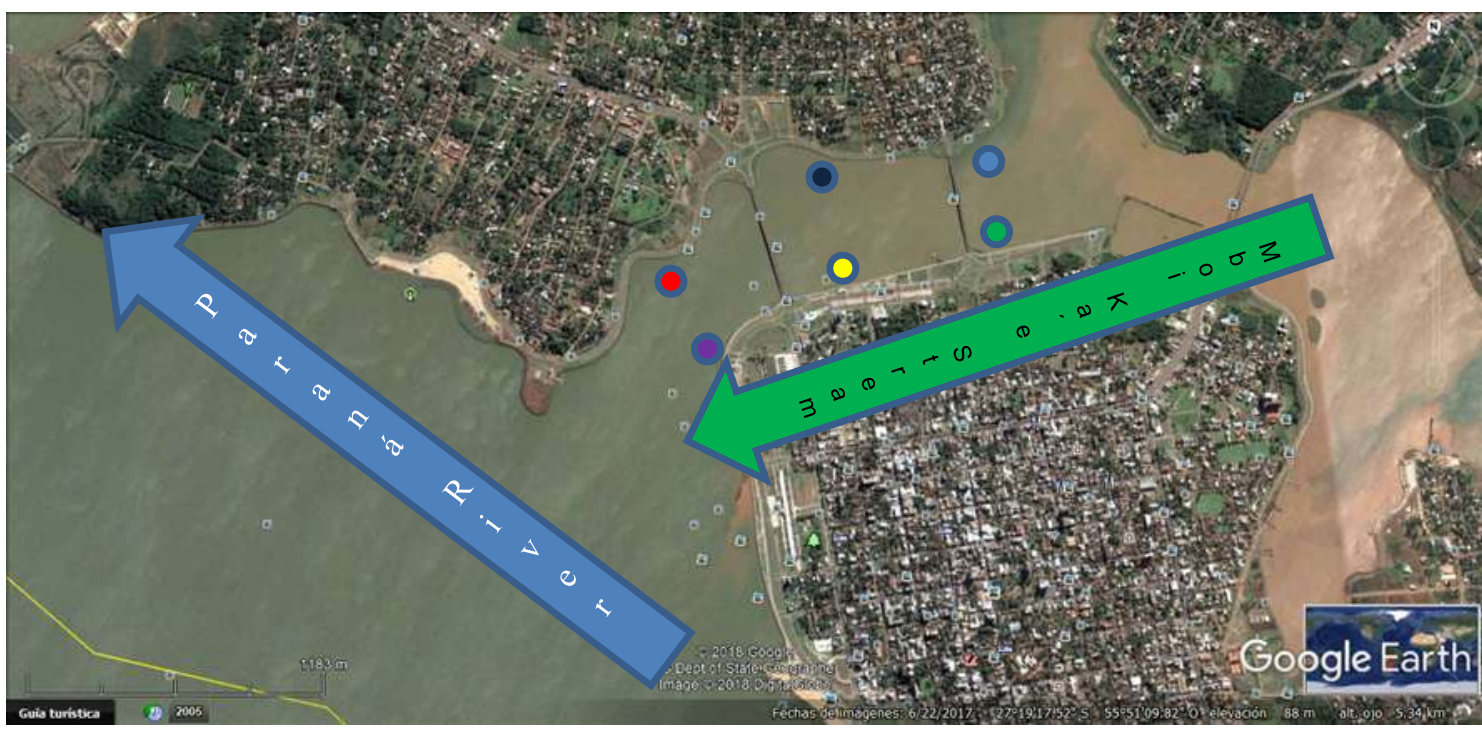

Figure 1:- Sampling sector for lab analyses

Reference: - Sampling sector $\mathrm{N}^{\circ}$ 1: $\mathrm{N}^{\circ} \bigcirc \mathrm{N}^{\circ}$ 3: $\mathrm{N} \mathrm{N}^{\circ}$ 4: $\bigcirc \quad \mathrm{N}^{\circ}$ 5: $\quad \mathrm{N}^{\circ}$ 6:

\section{Results and Discussion:-}

In this research, three types of phytoplankton were identified in the Mboi Ka'e stream of the city of Encarnación. They were Cyanophyta, Chlorophyta and Bacillariophyta in the following proportions: 43, 43 and 14\% respectively.

\section{Taxa identified in the study}

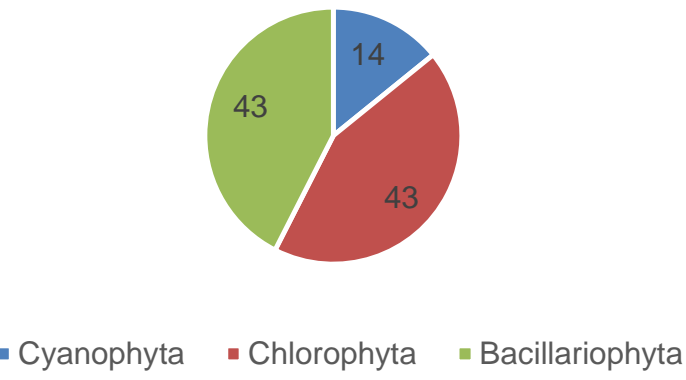

Figure 2:- Graph of the types of phytoplankton identified in the Mboi Ka'e stream

The analysis of variance presented significant statistical difference for the class Cyanophyta for the seasons and the species within the class, on the other hand, the class Chlorophyta presented statistical difference not significant for the two effects, the class Bacillariophyta presented non-significant difference for the effect of the seasons, the difference was highly significant for the different species within the class.

Table 1:- Population per milliliter per class identified in four seasons of the year in the Mboi Ka'e stream, Encarnación- 2015.

\begin{tabular}{|l|c|c|c|c|}
\hline Seasons & Cyanophyta & Chlorophyta & Bacillariophyta & Average \\
\hline Winter & $21,71 \mathrm{a}$ & 2,13 & 3,80 & 9,21 \\
\hline Spring & $29,82 \mathrm{a}$ & 5,76 & 8,34 & 14,64 \\
\hline Autumn & $97,29 \mathrm{ab}$ & 3,92 & 1,88 & 34,36 \\
\hline Summer & $120,71 \mathrm{~b}$ & 1,74 & 1,66 & 41,37 \\
\hline Average & $\mathbf{6 7 , 3 8}$ & $\mathbf{3 , 3 9}$ & $\mathbf{3 , 9 2}$ & $\mathbf{2 4 , 9 0}$ \\
\hline Value p year seasons & $\mathbf{0 , 0 3 9 6}$ & $\mathbf{0 , 2 5 1 8}$ & $\mathbf{0 , 4 5 3 1}$ & \\
\hline
\end{tabular}




\begin{tabular}{|l|c|c|c|c|}
\hline Value $\mathbf{p}$ types & $\mathbf{0 , 0 6 8 6}$ & $\mathbf{0 , 1 3 7 9}$ & $<\mathbf{0 , 0 0 0 1}$ & \\
\hline
\end{tabular}

Different letters indicate significant differences $(\mathrm{p}<=0.05)$

The Cyanophyta type showed a variation in the number of individuals according to the different seasons of the year. It is observed that the largest amount was presented in the summer being statistically similar to the amount found in the fall, understanding that population decreases as seasons changes, which could be associated to the variations that occur between the seasons of the year in the studied environment. It could be inferred that this decrease is due to the variation of environmental factors such as the decrease in photoperiod and temperature. The results obtained in this study coincide in part with that expressed by Meichtry de Zaburlín et al. (2013) who expressed the presence of dominant populations of phytoplankton corresponding to Cryptophyceae and Bacillariophyceae, likewise the above mentioned authors found that the Cyanophyceae vary in quantity according to the changes of the different seasons of the year in the Paraná river where the Mboi Kaé stream ends.

\section{Conclusion:-}

In this study it was shown that the phytoplankton population in the Mboi Ka'e stream basin is dominated by three main species: Cyanophyta, Chlorophyta and Bacillariophyta. Determining a variation in the population density in the taxon Cyanophyta in the summer and autumn in relation to the other taxa, from which it is understood that the increase in the population of the aforementioned phytoplankton class increased in the warmer months.

Thanks to the Consejo Nacional de Ciencias y Tecnologías (CONACYT) for the scholarship for the doctorate.

\section{References:-}

1. Reynolds, C.S. 1984. The ecology of freshwater phytoplankton. Cambridge University Press, Cambridge. 384 p.

2. Platt, T., P. Jauhary \& S. Sathyebdranath. 1992. The importance and measurement of new production. In: P. Falkowski \& A. Woodhead (eds.). Primary productivity and biogeochemical cycles in the sea. Environ. Sci. Res., 43: 273-284 p.

3. Oliva-Martínez, M; Godínez, J; Zuñiga, C. 2014. Biodiversity of phytoplankton of inland waters in Mexico. Mexican Journal of Biodiversity, Suppl. 85: 54-61 p.

4. Meichtry of Zaburlín, N; Vogler, R; Llano, V; Martens, I. 2013. Phytoplankton of the Yacyretá reservoir (Argentina-Paraguay) a decade after its completion. Mexican Journal of Biodiversity 84: 225-239 p.

5. Thornton, K. W., B. L. Kimmel and F. E. Payne. 1990. Reservoir limnology: ecological perspectives. John Wiley \& Sons, New York. 246 p.

6. Dos Santos, M. 2016. Algae from Paraguay. Characteristics and importance, sampling in Paraguay, key identification and illustration. San Lorenzo FACEM, 2016. 234 p.

7. Bicudo, C.E.D. M \& Menezes, M. 2006. Algae genera of continental waters of Brazil (chave for identifacação e descriçoes). São (2nd ed.) Sao Carlos- Brazil: Rima editor. 490 p.

8. Bourelly, P. 1970. Les algues d'eau douce III: N Boubee et cie, Paris.

9. Anagnostidis, K \& Komarek, J. 1989. Modern Approach to the Clasification Systen of Cyanophytes Osilatoriales.

10. Huber-Pestalozzi, G. (1955). Das Phytoplankton des Süsswassers. Systematik und Biologie. 4. Teil: Euglenophyceen. E. Schweizerbart'sche Verlagsbuchhandlung (Nägele u. Obermiller), Stuttgart. 606 pp. + pls $1-114$.

11. Conforti, V. and Tell, G. 1986. Ultrastructure of the loriga of Trachelomonas Ehr. (Euglenophyta) in Scanning Electron Microscope (SEM). Nova Hedwigia 43 (1-2): 45-79.

12. Krammer, K. \& Lange-Bertalot, H. (1986). Bacillariophyceae, 1. Teil: Naviculaceae. In: Süßwasserflora von Mitteleuropa (H. Ettl, J. Gerloff, H. Heynig \& D. Mollenhauer, eds), Band 2/1, 876 pp. Gustav Fischer Verlag, Stuttgart, New York. 